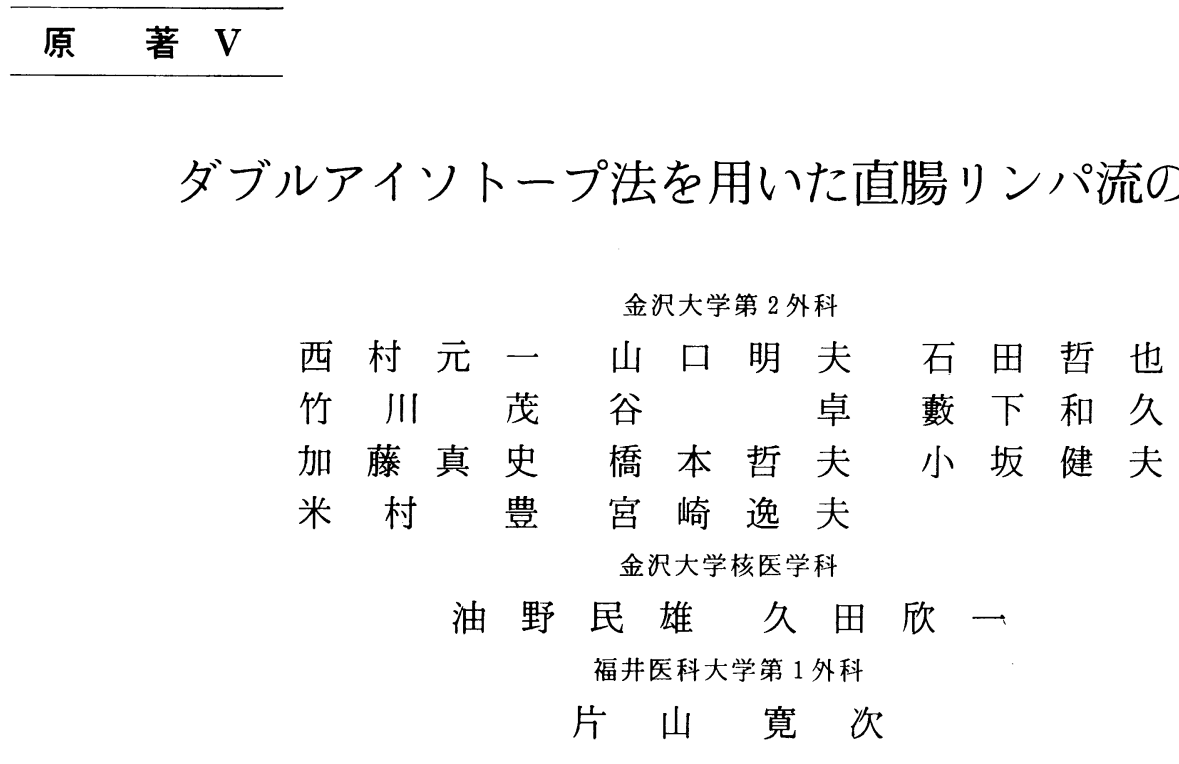

直腸癌治癒切除例13例に対して，2 種の核種（ ${ }^{99 m}$ Tc-sulfur colloid, ${ }^{111}$ In-colloid）を用いた RI lymphography を施行し上部直腸 $(\mathrm{Ra})$, 下部直腸 $(\mathrm{Rb})$ のリンパ流の検討を行った. 手術前日に RI を直腸粘膜下層 に注入し, 術後切除標本より摘出したリンパ節を詳細なマッピングの上, リンパ節を上方向経路, 側方向経 路および大動脈周囲の大きく 3 つに分類しそれぞれの RI uptake 值を測定し検討した. その結果, 上部, 下部 直腸からのリンパ節は上方向経路に加えて, 内腸骨リンパ節を中心とした側方向経路も重要であると考えら れ，また大動脈周囲リンパ節の RI 陽性率が50.0\%と下腸間膜リンパ節の $38.5 \%$ よ高率であったことより 上方向リンパ流以外による大動脈周囲リンパ節への経路が示唆された. それに加え，大動脈周囲リンパ節の うち大動静脈間, 大動脈前, 大動脈左の RI の取り込みが高率であり，同部位の郭清を考虑すべきと思われた.

索引用語 : RI lymphography, ${ }^{99 m} \mathrm{~T}$ c-sulfur colloid, ${ }^{111} \mathrm{In}$-colloid, 大動脈周囲リンパ節, 直腸リンパ流

\section{はじめに}

従来, 進行直腸癌の外科的治療に対しては側方郭清や 大動脈周囲の郭清を伴う拡大手術が行われてきたが1), 術後の性機能や排尿機能の障害が問題となり, 最近では 一律に拡大郭清を行うのではなく, 癌腫の進行に見合っ た適切な郭清が求められている. そのためには直腸のリ ンパ流を把握した上で根治性を失することのない系統的 な郭清を行うことが必要である. 今回, 2 種の radioisotope（RI）を用いた double isotope RI lymphography (以下 double isotope 法) を施行し上部直腸（Ra）およ び下部直腸 $(\mathrm{Rb})$ のリンパ流について検討を行ったので 報告する.

\section{I. 対象と方法}

直腸癌治癒切除可能例に対して, 手術前日に経内視鏡
的に非癌部粘膜下層へ ${ }^{99 \mathrm{~m}} \mathrm{Tc}$-sulfur colloid と ${ }^{111} \mathrm{In}-\mathrm{col}$ loid を各々 $0.5 \mathrm{ml}$ 注入した. ${ }^{99 \mathrm{~m}} \mathrm{Tc}$-sulfur colloid は ${ }^{99 \mathrm{~m}} \mathrm{Tc}$-pertechnetate $1.0 \mathrm{ml}$ に gelatin $1.2 \mathrm{ml}$ と塩酸 $0.2 \mathrm{ml}$ を加え混和し, 湯浴中に 5 分間放置後, クエン酸 緩衝液 $0.4 \mathrm{ml}$ を加え作製した. また ${ }^{111} \mathrm{In}$-colloid は, ${ }^{111} \mathrm{InCl}_{3}$ に $10 \%$ マンニトール $0.2 \mathrm{ml}$ を加えたのち, リン 酸緩衝液と0.01規定 $\mathrm{NaOH}$ で $\mathrm{PH}$ を7.4に調節し， 1 時間静置してから使用した.

術後, 切除標本よりリンパ節を摘出し, 詳細なマッピ ングの上, リンパ節 1 個あたりの RI up take 值を auto well scintillation-counter で24時間間隔で 2 回測定 した. その後 ${ }^{99} \mathrm{mTc}$ と ${ }^{111} \mathrm{In} の$ 半減期の差 ${ }^{99} \mathrm{mTc}: 6.04$ 時間, ${ }^{111} \mathrm{In}: 2.81$ 日) を利用して各リンパ節の ${ }^{99} \mathrm{mTc}$ と ${ }^{111}$ In の取り込み（cpm）を算出し，200 cpm 以上のもの を陽性とした 2)（表 1). 今回 double isotope 法施行例 中, 組織学的リンパ節転移が $n_{0}$ である症例11例および 
表 $199 \mathrm{~m} \mathrm{Tc},{ }^{111} \mathrm{In}$ 取り込み值算出法

1 回目測定值 $\left(A_{1}\right)=T+I$

2 回目測定值 $\left(A_{2}\right)=T \times t+I \times i$

$$
\left(\begin{array}{l}
\mathrm{T}:{ }^{99 \mathrm{~m}} \mathrm{Tc} \text { 測定値 } \\
\mathrm{I}:{ }^{111} \mathrm{In} \text { 測定値 } \\
\mathrm{t}:{ }^{99 \mathrm{~m}} \mathrm{Tc} \text { の減衰率 } \\
\mathrm{i}:{ }^{111} \mathrm{In} \text { の減衰率 }
\end{array}\right)
$$$$
\mathrm{T}=\frac{\mathrm{A}_{2}-\mathrm{A}_{1} \mathrm{i}}{\mathrm{t}-\mathrm{i}}, \mathrm{I}=\frac{\mathrm{A}_{2}-\mathrm{A}_{1} \mathrm{t}}{\mathrm{i}-\mathrm{t}}
$$

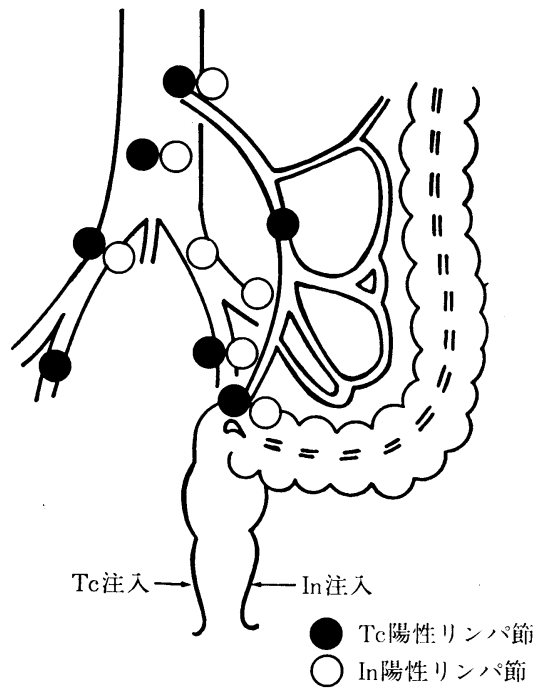

図 1 症例

$\mathrm{n}_{1}$ 症例 2 例の計13例を用いて直腸のリンパ流の検討を 行った.

またリンパ流を解析する上でリンパ節を (1)腸管軸方向 (2)上方向 : 傍直腸リンパ節, 上直腸リンパ節, 下腸間膜 リンパ節の 3 群(3)側方向 : 総腸骨リンパ節, 内腸骨リン パ節（閉鎖孔リンパ節，中直腸動脈リンパ節を含む）， 外腸骨リンパ節の 3 群(4)大動脈周囲リンパ節の大きく 4 つに分類し検討した.

\section{II. 結 果}

\section{1. 症 例}

$\mathrm{Rb}$ の右壁に ${ }^{99 \mathrm{~m}} \mathrm{~T}$ c-sulfur colloid, 左壁に ${ }^{111} \mathrm{In}$-colloid を注入した症例では，上方向経路のリンパ節には両方の 核種とも取り込まれているのに対して，側方向経路をみ ると In 注入側の対側である右の外腸骨リンパ節ではIn が取り込まれず，逆に左の総腸骨リンパ節，外腸骨リン パ節では Tc が取り込まれていなかった（図 1 ).

\section{2. 腸管軸方向の RI 陽性率}

$\mathrm{RI}$ の粘膜下層内での広がりを半径 $2.5 \mathrm{~cm}$ 上考え，大
表 2 腸管軸方向の RI 陽性率

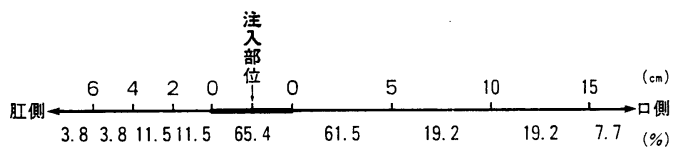

腸癌取扱い規約 ${ }^{3)}$ に準じて口側腸管を $5 \mathrm{~cm}$ 間隔，肛側 腸管を $2 \mathrm{~cm}$ 間隔で区切り，それぞれの区域のリンパ節 の RI 陽性率を検討した. 口側では $5 \mathrm{~cm}$ までの範囲の 陽性率は $61.5 \%$ と高率であったが, $5 \sim 10 \mathrm{~cm}, 10 \sim 15 \mathrm{~cm}$ の範囲では $19.2 \%$ と減少し， $15 \mathrm{~cm}$ 以上の陽性率は $7.7 \%$ にすぎなかった，また，肛側の RI 陽性率は口側と比較 して低率であり，肛側 $2 \mathrm{~cm}$ まで， $4 \mathrm{~cm}$ までの陽性率 はそれぞれ11.5\%にすぎなかった（表 2 ).

3.上方向, 側方向の RI 陽性率, RI 陽性度 各リンパ節の RI 陽性率をみると, 上方向では, 傍直 腸リンパ節 $92.3 \%$ ，上直腸リンパ節 $57.7 \%$ ，下腸間膜リ ンパ節 $38.5 \%$ と遠位になるにつれ陽性率の低下を認め た. 側方向では, 総腸骨リンパ節 $46.2 \%$, 内腸骨リンパ 節 $61.5 \%$ ，外腸骨リンパ節 $26.9 \%$ と上方向と比較して陽 性率は低かった。 大動脈周囲リンパ節の RI 陽性率は $50.0 \%$ と下腸間膜リンパ節と比較して高率であった。 た RI 陽性度も RI陽性率とほぼ同様の傾向を認めた (表 3 ).

4. RI 注入部位の高さと RI 陽性率

$\mathrm{RI}$ 注入部位の高さにより $\mathrm{Ra}$ 注入群 $(\mathrm{n}=9)$ と $\mathrm{Rb}$ 注入群 $(\mathrm{n}=7)$ に分け各リンパ節の RI 陽性率につい て検討したところ， $\mathrm{Ra}, \mathrm{Rb}$ 注入の両群ともに側方向よ りも上方向が優位であり，下腸間膜リンパ節より大動脈 周囲リンパ節の取り込みが高率であるという点ではほぼ 同様の結果であった. しかしながら， Ra 注入群では下 腸間膜リンパ節の陽性率が $44.4 \%$ と $\mathrm{Rb}$ 注入群の $35.3 \%$ と比較してやや高率であり，逆に外腸骨リンパ節では $22.2 \%$ Rb 注入群よりも低率であった（表 4 ).

5. RI 注入部位の壁在性と RI 陽性率

リンパ流の laterality を検討する目的で, RI の注入 部位により右壁注入群 $(\mathrm{n}=7)$ と左壁注入群 $(\mathrm{n}=8)$ に分け，側方向のリンパ節の RI 陽性率を検討した。 そ の結果, 総腸骨リンパ節, 内腸骨リンパ節, 外腸骨リン パ節とも注入側の陽性率の方が若干高率であったが，反 対側にも RI 陽性リンパ節が認められ，その laterality は明かでなかった（表 5 ).

6. 大動脈周囲リンパ節の RI 陽性率, 陽性度

まず，大動脈周囲リンパ節を大静脈前（大静脈右を含 む), 大動静脈間, 大動脈前, 大動脈左の 4 群に分類し, それぞれの RI の取り込みを検討した. 大静脈前の RI 陽性率，陽性度ともに0\%であったのに対して，大動静 
表 3 上方向・側方向の RI 陽性率・RI陽性度

\begin{tabular}{|c|c|c|c|c|c|c|c|}
\hline & $\begin{array}{l}\text { 傍 直 腸 } \\
\text { リンパ䬣 }\end{array}$ & $\begin{array}{l}\text { 上直腸 } \\
\text { リンパ節 }\end{array}$ & $\begin{array}{l}\text { 下腸間膜 } \\
\text { リパ゚節 }\end{array}$ & $\begin{array}{l}\text { 総 腸 骨 } \\
\text { リンパ節 }\end{array}$ & $\begin{array}{l}\text { 内 腸 骨 } \\
\text { リン゚節 }\end{array}$ & $\begin{array}{l}\text { 外 腸 骨 } \\
\text { リン゚䬫 }\end{array}$ & 大動脈周囲 \\
\hline $\begin{array}{l}\mathrm{RI} \text { 陽性摔 } \\
(\mathrm{n}=26)\end{array}$ & 92.3 & 57.7 & 38.5 & 46.2 & 61.5 & 26.9 & 50.0 \\
\hline RI 陽性度 & $\begin{array}{c}34.0 \\
(126 / 371)\end{array}$ & $\begin{array}{c}25.7 \\
(38 / 148)\end{array}$ & $\begin{array}{c}24.4 \\
(42 / 172)\end{array}$ & $\begin{array}{c}19.9 \\
(30 / 151)\end{array}$ & $\begin{array}{c}15.5 \\
(92 / 593)\end{array}$ & $\begin{array}{c}6.6 \\
(10 / 152)\end{array}$ & $\begin{array}{c}23.3 \\
(89 / 382)\end{array}$ \\
\hline
\end{tabular}

表 4 RI 注入部位の高さとRI陽性率

\begin{tabular}{|c|c|c|c|c|c|c|c|}
\hline & $\begin{array}{l}\text { 傍 直 晹 } \\
\text { リンパ節 }\end{array}$ & $\begin{array}{l}\text { 上直 腸 } \\
\text { リンパ節 }\end{array}$ & $\begin{array}{l}\text { 下腸間膜 } \\
\text { リハパ節 }\end{array}$ & $\begin{array}{l}\text { 総 腸 骨 } \\
\text { リンパ節 }\end{array}$ & $\begin{array}{l}\text { 内腸 骨 } \\
\text { リンパ節 }\end{array}$ & $\begin{array}{l}\text { 外腸 骨 } \\
\text { リンパ節 }\end{array}$ & 大動脈夙囲 \\
\hline $\begin{array}{l}R a \text { 注入 } \\
(n=-9)\end{array}$ & 88.9 & 55.6 & 44.4 & 55.6 & 66.7 & 22.2 & 55.6 \\
\hline $\begin{array}{l}\mathrm{Rb} \text { 注入 } \\
(\mathrm{n}=7)\end{array}$ & 94.1 & 58.8 & 35.3 & 47.1 & 58.8 & 29.4 & 47.1 \\
\hline
\end{tabular}

表 5 RI注入部位の壁在性と RI 陽性率

\begin{tabular}{cccccccc}
\hline & \multicolumn{3}{c}{$\begin{array}{c}\text { 総腸骨リンパ節 } \\
\text { 右 }\end{array}$} & \multicolumn{2}{c}{ 内腸骨リンパ節 } & \multicolumn{2}{c}{ 外腸骨リンパ節 } \\
& 右 & 左 & 右 & 左 \\
\hline $\begin{array}{c}\text { 右壁注入 } \\
\mathrm{n}=7\end{array}$ & 28.6 & 14.3 & 71.4 & 42.9 & 14.0 & 0 \\
\hdashline $\begin{array}{c}\text { 左壁注入 } \\
\mathrm{n}=8\end{array}$ & 25.0 & 37.5 & 50.0 & 87.5 & 25.0 & 37.5 \\
\hline
\end{tabular}

(\%)



図 2 大動脈周讲リンパ節の RI 陽性率

脈間, 大動脈前, 大動脈左の RI 陽性率はそれぞれ 30.8 $\% ， 34.6 \% ， 42.3 \%$ と大動脈左において幾分高率であっ たが，その陽性度については 3 群間に差は認められなか

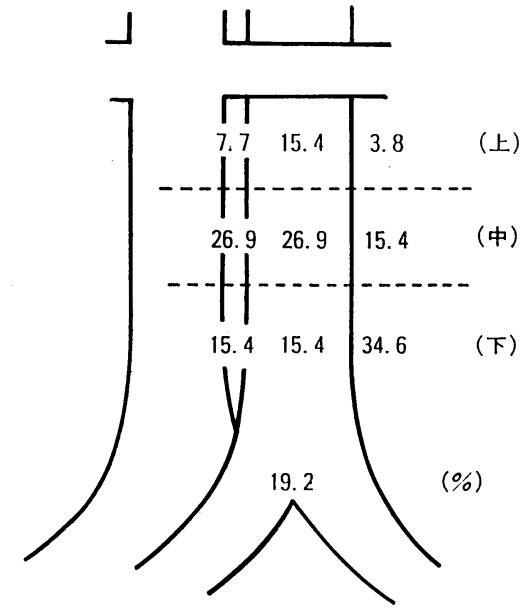

図 3 大動脈周囲リンパ節を 9 分割した場 合の各区域の RI 陽性率

った (図 2 ).

次に, RI の取り込みを認めた大動静脈間, 大動脈前, 大動脈左を下腸間膜動脈を中心として上下 $2 \mathrm{~cm}$ に挾ま れる範囲と, それより上方, それより下方の 9 力所およ 動脈分岐部の10力所に分け検討を行った. その結果, 最 も高率であったのは大動脈左下の $34.6 \%$ であり, ついで 大動脈前中, 大動静脈間中の $26.9 \%$, 大動脈分岐部の 19.2 \%であった（図 3 ).

\section{III. 考察}

進行直腸癌の治療成績は, 従来より行われている側方 郭清や大動脈周囲の郭清をともなう拡大手術により確実 
に向上した4).しかしながら-一方では, 術後の性機能障 害, 排尿障害をはじめとする機能障害が問題となり，機 能を温存する術式も望まれるようになってきている。す なわち根治性を失わず, かつ過大な郭清を行わない術式 が望まれ，そのためには直腸のリンパ流を考慮した系統 的な郭清が必要である.

直腸のリンパ流に関する研究は1895年の Gerota ら5) を最初として色素, 活性炭, RI を利用したものなど種 々の報告がなされている ${ }^{6-8)}$. 当教室では 上部消化管の リンパ流の 検索のために, 昭和57年より ${ }^{99 \mathrm{~m}} \mathrm{Tc}$-sulfur colloid を用いた RI lymphography を施行し9), 昭和

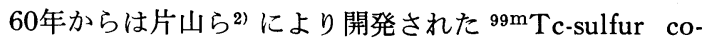
lloid と ${ }^{111}$ In-colloid を併用した double isotope RI lymphography を行ってきた. Double isotope 法は 1 症例 で 2 カ所からのリンパ流を観察できる利点があり, また 当科で使用している ${ }^{99 m}$ Tc-sulfur colloid と ${ }^{111}$ In-colloid は, 通常 RI lymphography に用いられている ${ }^{99 m}$ Tcrhenium colloid と比較して粒子径が約 $50 \mu \mathrm{m}$ と大きく, また labeling index も高いため血中，尿中への移行を 認めず contamination の危険は少なく実際のリンパ流 をよく反映しているものと思われる ${ }^{10,11)}$. そこで今回著 者らは, double isotope 法を用いて直腸のリンパ流につ いて検討を行った.

まず腸管軸方向リンパ節の RI 取り込みをみると，口 側 $5 \mathrm{~cm}$ までの陽性率は $61.5 \%$ と高率であったのに対し て，それより口側の RI の取り込みは極端に低率であっ た. また注入部位より肛側の RIの取り込みは，ほぼ 4 $\mathrm{cm}$ までに限られており，その陽性率も上方向，側方向 リンパ節の 3 群, 4 群リンパ節の陽性率よりも低率であ った. すなわち今までに使われてきた大腸癌取扱い規約 に従いリンパ節分類を行らとかなりのアンバランスが生 じているものと考えられる.

次に注入例全体で上方向の流れと側方向の流れを比較 した. 勝又ら ${ }^{12)}$ は ${ }^{99 \mathrm{~m}} \mathrm{~T}$ c-rhenium colloid を用いた検討 で上方向の流れは側方向の流れより優勢であり，また上 方向では遠位になるほど陽性度の低下を認めたとしてい る. 今回の検討でもほぼ同様であり，上部，下部直腸か らのリンパ流は上方経路が主要経路と考えられた.

さらに詳細な情報を得るために RI 注入部位別に検討 を行った. 一般に, $\mathrm{Rb}$ の癌腫は $\mathrm{Ra}$ と比較して側方向 のリンパ節転移が多いとされ，また直腸癌が左，右壁の どちらかに位置する症例では同側一の側方転移が多い傾 向がみられるとされている13,14). しかしながら今回の検 討では $\mathrm{Ra}, \mathrm{Rb}$ 注入で各リンパ節の RI 取り込みにあ まり差は認められず，また注入側における側方向リンパ 節の RI 陽性率は対側より高率であったものの完全な laterality は認められなかった.この原因としては，RI を $0.5 \mathrm{ml}$ 注入すると粘膜下で径 $4 \sim 5 \mathrm{~cm}$ に広がるた め2) 広い範囲のリンパ流をとらえていると思われ，注入 量を少量にした詳細な検討が必要と思われる.

一方，今回の検討では下腸間膜リンパ節よりも大動脈 周囲リンパ節の RI 陽性率が高率であった.このことは

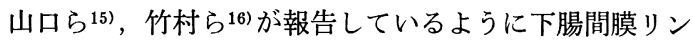
パ節を経由しない大動脈周囲リンパ節への経路が存在す るためと考えられる.そこで大動脈周囲リンパ節を細分 化することにより大動脈周囲への経路について検討を行 った.

まず，大動脈周囲リンパ節を縦に 4 群に分け RI の 取り込みを比較した結果では, 大動静脈間, 大動脈前, 大動脈左の 3 群ではほぼ同程度の RI の取り込みを認め たのに対して，大静脈前ではまったく取り込みを認めな かった．直腸から大動脈周囲リンパ節へ至る経路は上直 腸動脈から下腸間膜動脈に沿った上方向経路と内腸骨動 脈から総腸骨動脈に沿った側方向経路の大きく 2 つが考 えられるが，いずれの経路も大動静脈間および大動脈前 面, 左側を通り, さらに深部の大動脈背側のリンパ節に 流入する経路が本流であるとされており ${ }^{17,18)}$, 今回の結 果とあわせると直腸からのリンパ流と大静脈前面から右 側にかけてのリンパ節との直接的な関連は乏しいものと 考えられ，この部位の郭清の意義は少ないと思われる. また大動脈周囲リンパ節を高さで分けた検討において下 腸間膜動脈根部より下方である大動脈左の RI 陽性率が 最も高率であったことは，同部位へ直接流入する経路が 存在するためと考えられ，また大動脈分岐部の陽性率が $19.2 \%$ と高率であったことは，この部位が側方向からの 経路の中間地点になっている可能性があるためと思われ た. 以上より, 大動脈周囲リンパ節への流入経路として は，(1)下腸間膜動脈に沿って流入する経路，(2)上直腸動 脈周囲より直接大動脈の左側一流入する経路, (3)側方向 である内腸骨動脈から総腸骨動脈に沿って上行する経 路，の少なくとも 3 経路が存在すると思われ，リンパ節 転移を有する症例では 3 群リンパ節である下腸骨間膜リ ンパ節に転移を認めない症例においても大動脈周囲リン パ節への skip metastasis を念頭に入れ，大動静脈間よ り左側を中心とした大動脈周囲リンパ節の郭清も考慮す べきであろうと考えられた.

\section{IV. まとめ}

ダブルアイソトープ法を用いて直腸のリンパ流につい て検討を行い, 以下のような結論を得た.

1）上方向経路である傍直腸，上直腸，下腸間膜リン パ節の RI 陽性率は，おのおの $92.3 \% ， 57.7 \% ， 38.5 \%$ 
であり側方向経路よりも高率な取り达みを認めた。

2）大動脈周囲リンパ節の RI 陽性率は $50.0 \%$ と下腸 間膜リンパ節の $38.5 \%$ ๖も高率であった.

3）大動脈周囲 リンパ 節のうち大動静脈間，大動脈 前, 大動脈左の RI 陽性率はそれぞれ $30.8 \%, 34.6 \%$. $42.3 \%$ あっったのに対して大静脈前面より右側のリンパ 節では RI の取り込みは認められなかった。

\section{文献}

1）北條慶一：直腸癌のリンパ節転移と予後. 消外 $9: 199-205, \quad 1986$

2) 片山寛二, 米村 豊, 橋本哲夫ほか: Double Isotope 法を用いた胃リンパ流の検討. 日消外 会誌 $18: 1750,1985$

3）大腸癌取扱、規約, 改訂 4 版.

4）北條慶一：結腸, 直腸. 臨外 $35: 657-666$. 1980

5) Gerota D : Die Lymphgefasse des Recrums und des Anus. Arch Anat Physiol $7: 240-$ 256, 1895

6) Block IR: A more radical perineal phase for abdominoperineal resection of rectum for carcinoma. Surg Gynecol Obstet 107 : 667671, 1958

7）森谷宣皓, 小山靖夫, 北條慶一：直腸癌リンパ 節郭清の指標としての炭素 ( $\mathrm{CH} 40)$ によるリ ンパ節染色. 日本大腸肛門病会誌 $38: 136-$ 143,1985

8) Bartholdson L, Hultborn A, Hulten L, et al: Lymph drainage from the upper and middle third of the rectum as demonstrated by ${ }^{198} \mathrm{Au}$. Acta Radiol Ther $16: 352-360$, 1977

9）米村 豊, 沢 敏治, 藤井久丈ほか：ラジオア イソトープを用いた胃 RI リンホグラフィーな らびに胃リンパ路の検討. 北陸外会誌 $2: 49-$ 54,1983

10）中嶋憲一，小泉 潔，油野民雄ほか：ラットに おける ${ }^{99 m}$ Tc-rhenium の体内分布. 核医学 $18: 967-971,1981$

22) 作本修一, 三村 久, 佐藤四三ほか: Hepatohistgram 用製剂としてのIn-111-コロイドの開 発。核医学 $22: 1235,1985$

12）勝又貴夫, 小平 進, 寺本龍生ほか：直腸リン パ節のラジオアイソトープリンパ造影. 日本大 腸肛門病会誌 $37: 557-561,1984$

13）加藤岳人, 高橋 孝, 太田博俊ほか：直腸癌側 方リンパ節転移の検討. 日消外会誌 $19: 963-$ 968,1986

14）畦倉 薰, 浜畑幸弘, 上野雅資ほか：直腸, S 状結腸リンパ流の検討. リンパ学 $11: 153-$ 160,1988

15）山口明夫, 石田哲也, 谷卓ほか： $S$ 状結腸リ ンパ流の検討. 外科診療 $30: 361-365,1988$

16）竹村克二, 安藤昌之, 岡部 聡ほか：下部直腸 リンパ流. 日本大腸肛門病会誌 $39: 113-120$, 1986

17）佐藤健次, 佐藤達夫 : 腸骨血管周囲のリンパ系 について.リンパ学 $8: 73-76,1985$

18）出来尚史, 佐藤達夫: 腹大動脈周囲のリンパ 系. リンパ学 $7: 51-54,1984$ 


\title{
Lymphatic Drainage from the Rectum as Demonstrated by Double Isotope Method
}

\author{
G. Nishimura, A. Yamaguchi, T. Ishida, S. Tani, \\ K. Yabushita, M. Kato, T. Hashimoto, T. Kosaka, \\ Y. Yonemura and I. Miyazaki \\ Department of Surgery II, School of Medicine, Kanazawa University \\ T. Aburano and K. Hisada \\ Department of Nuclear Medicine, School of Medicine Kanazawa University \\ K. Katayama \\ The First Department of Surgery, Fukui Medical School
}

Lymphatic drainage from the rectum was studied in 13 cases by the double isotope transport method using ${ }^{99 m} \mathrm{Tc}$-sulfur colloid and ${ }^{111} \mathrm{In}$-colloid, following their submucosal injection into the rectum on the day before operation. Surgically dissected lymph nodes were classified into the following groups: Group 1 of the upward route, made up of the para-rectal nodes, superior rectal nodes and inferior mesenteric nodes; Group 2 of the lateral pelvic route, consisting of the common iliac nodes, internal iliac nodes and external iliac nodes, and Group 3, comprising the para-aortic nodes. The nodes were individually assayed for the uptake of radioactivity by a well-type scintiration counter.

The study revealed that upward route from the rectum would be the main lymphatic stream: that the lateral pelvic route would be another important route for lymph node metastasis, and that there would be other routes to para-aortic nodes other than the upward lymphatic drainage: the inter-aorticovenous, preaortic and left lateroaortic nodes would also be the key to successful lymph node dissection. 